15. Федосеев Н. Каллатийцы на Босфоре // Kallatida, Editura «Callasprint», Mangalia, 2014. C. 15-36.

16. Georgescu V., Ionescu M. Cercetari perieghetice in teritoriul callatian // Studii si cercetari de istorie veche si arheologie. 1997. Vol. 48, № 2. P. 155-176.

17. Preda C., Georgescu N. Săpăturile de salvare de la Mangalia din 1972 - necropola callatiană din zona stadionului // Pontica. 1975. № 8. P. 53-56.

18. Preda C., Bârlădeanu E. Săpăturile arheologice de salvare din zona de SV (şantierul naval Mangalia) a Mangaliei // Pontica. 1979. Vol. 12. P. 97-108.

19. Saprykin S., Păslaru I. Noua inscripţia din Callatis în onoarea impăratului Augustus // Kallatida, Editura «Callasprint». Mangalia, 2014. P. 39-48.

20. Păslaru I., Colesniuc S. O friză cu reprezentări de divinităti descoperită la Callatis // Pontica. 2004-2005. № 37-38. P. 413-418.

21. Preda C., Popescu Em., Diaconu P. Săpăturile arheologice de la Mangalia // Materiale si Crecetari Arheologice. 1962. № 8. P. 439-458.

22. Colesniuc S., Istoria singurului papirus descoperit in Romania // Editura «Callasprint». Mangalia, 2013. 78 p.

23. Preda C. Archaeological discoveries in the Greek cemetery of Callatis-Mangalia // Dacia. Noua Serie. 1961. Vol. V. P. 275-303.
24. Preda C., Tezaurul de la Mangalia // Studii si cercetari de istorie veche. 1961. № 12. P. 241-250.

25. Preda C. Una tomba con volta scoperta presso Mangalia - Callatis // Dacia. Noua Serie. 1962. № 6. Р. 157-172.

26. Федоров Г.Б. Дневная поверхность. М., 1966. $384 \mathrm{c}$.

27. Словарь античности. М.: Прогресс, 1989. $704 \mathrm{c}$.

28. Жмудь Л.Я. Орфический папирус из Дервени // Вестник древней истории. 1983. № 2. С. 118-139.

29. Most G.W. The Fire Next Time. Cosmology, Allegories, and Salvation in the Derveni Papyrus // Journal of Hellenic Studies. 1997. № 117. P. 117-135.

30. Betegh G. The Derveni Papyrus: Cosmology, Theology and Interpretation // Cambridge University Press, Cambridge, 2004. 456 p.

31. Страбон. География в 17 книгах. М.: ОлмаПресc, 2004. 638 c.

32. Солопова М.А. Гераклид Лемб // Античная философия: Энциклопедический словарь. М.: Прогресс-Традиция, 2008. 896 с.

33. Schorn S. Satyros aus Kallatis: Sammlung der Frauugmente mit Kommentar. Basel: Schwabe, 2004. 544 p.

\title{
THE RETURN OF THE ANCIENT PAPYRUS: THE DISCOVERY AND FATE OF THE ANCIENT GREEK PAPYRUS FROM MANGALIA (ROMANIA)
}

(C) 2018

Yarovoy Evgeny Vasilyevich, doctor of historical sciences, head of Archeology, History of the Ancient World and Middle Ages Department Moscow Region State University (Moscow, Russian Federation)

Abstract. On the west coast of the Black sea excavations of ancient cities have been conducted for more than a century and a half. Among them, a special place is considered to be the Dorian colony of Kallatis, founded by immigrants from Heraclea of Pontius, most likely in the VI century BC. Currently on its territory there is a Romanian city of Mangalia. In 1959, during the excavations of the ancient mound on the Hellenistic burial ground, an ungraded burial in a stone sarcophagus was discovered. It was a backbone of an adult with a gilded bronze wreath. Near his hands there was an ancient Greek papyrus. For his conservation a Soviet restorer M. Alexander was invited, he managed to preserve the rarity. At the request of the Romanian side, he took the papyrus for restoration to Moscow, where his traces were lost. In 2001, Romanian archaeologists began searching for the papyrus. After three years of work in museums and libraries, they were able to locate the rest of the scroll. It turned out that they are stored in the Center of restoration "Grabar» in Moscow. As a result of the negotiations, thanks to the good will of the Russian side, it was possible to reach an agreement on the return of a unique discovery for Romania to its historical homeland.

Keywords: papyrus; laurel wreath; mound; sarcophagus; colony; Kallatis; Mangalia; Heracleia of Pontius; Dobrudzha; Romania; Moscow; Museum of archeology; Restoration Center; Alexandrovsky; Paslaru; Lesovoy; Black sea; Hellenistic burial ground; Orphic text; conservation.

\section{ЭТНИЧЕСКИЕ И АДМИНИСТРАТИВНЫЕ ГРАНИЦЫ: ОТ КОНФЛИКТНОСТИ К СТАБИЛЬНОСТИ (НА ПРИМЕРЕ ОРЕНБУРЖЬЯ ХVIII-XIX ВЕКОВ)} (C) 2018

Федорова Алла Владимировна, доктор исторических наук, профессор кафедры истории и философии Оренбургский государственный аграрный университет (2. Оренбург, Российская Федерация)

Аннотация. Осмысление исторического опыта взаимоотношений народов затрагивает политическую, экономическую и культурную сферы жизни людей. Этнокультурный и межконфессиональный диалог в полиэтническом пространстве постоянно находится в центре внимания исследователей. За последние два с половиной столетия в разных регионах бывшего СССР и за рубежом было опубликовано более 50 тыс. научных работ, посвященных истории Казахстана дореволюционного периода. Историки России и Казахстана, используя обширную документальную базу, изучают все стороны взаимодействия своих народов. Попрежнему предметом обсуждения является многогранная проблема российско-казахских отношений, в част- 
ности вхождение Казахстана в состав Российской империи в начале XVIII века. В статье рассматривается характер этого присоединения в контексте связей приграничных регионов. Автор опирается на подход, свободный от эмоционального влияния, отражает как негативные, так и позитивные последствия национальной политики империи. Колонизация казахской степи началась с территории Южного Урала, статья демонстрирует имевший место конфликтогенный потенциал, противоборство царизма и казахского общества. Предпринята попытка показать на материалах Оренбуржья, что, несмотря на все перипетии истории, у казахов с русским народом сложились искренние отношения добрососедства и сотрудничества.

Ключевые слова: Россия; Казахстан; Оренбургская губерния; Илекская крепость; Илецкая крепость; Сорочинская крепость; Рассыпная крепость; Оренбургская комиссия; пограничная линия; яицкие казаки; ревизия; малороссы; Коллегия иностранных дел; И.И. Неплюев; демография; киргиз-кайсаки; Средний жуз; Младший жуз; кочевники; плен; Абулхаир; Нурали-хан; набеги.

Проблема принятия казахами Российского подданства продолжает находиться в центре внимания российских и казахстанских историков. Для русских и казахов характерны отношения братства и доверия. Задача современного общества состоит в сохранении и укреплении этих отношений. [1, с. 9] Казахские учёные в большинстве своём отмечают «цивилизаторскую роль России по отношению к Востоку» [2-4].

Процесс превращения казахских земель в одну из национальных окраин Российской империи относится к XVIII в. В разработке данного курса важную роль сыграли устроители Оренбургского края И.К. Кириллов, В.Н. Татищев, В.А. Урусов, И.И. Неплюев.

Заселение казаками территории современного Оренбуржья активизировалось в 40-х годах XVIII в. Сведения об этом отражены в данных переписи 1740 г. и на составленной в 1741 г. «Табели о состоянии в нижеописанных новопостроенных от Самары до Оренбурга и в других местах крепостях, о казаках и протчих всякого звания пребывающих нелегулярных людях» [5, л. 48-50 об.]. В это время ещё не началось освоение казаками Тевкелевой и Переволокской крепостей, в ряде яицких крепостей находились лишь регулярные воинские команды.

Размещение казаков не предусматривалось, например, в Илекской крепости (Илецкая крепость «относилась к ведомству Яицкого войска»). Среди безжалованных казаков Илецкой крепости, обеспечивающих себя всем необходимым за счёт полученных сельскохозяйственных угодий, встречались казачьи командиры, писари и пушкари [6, с. 330].

Данные о служилых казаках в крепостях по рекам Самаре и Яику в 1741 г. приводятся в монографии самарского профессора Ю.Н. Смирнова «Оренбургская экспедиция (комиссия) и присоединение Заволжья к России в 30-40-гг. XVIII в.» [7, с. 124].

Наряду со служилыми казаками в крепостях находилось значительное число неслужащего мужского населения: отставные казаки, отставные солдаты, члены семей служащих и неслужащих казаков, различные родственники, работники и т.д.

Первоначальное оседлое население оренбургских пограничных линий составляли лица, записанные в казачье сословие, при этом не учитывалось их отношение к военной службе. $40 \%$ всех переселенцев составляли женщины.

Крупным поселением на Яике была Илецкая слобода (с 1746 г. - станица) [8, с. 89-90]. Расселенное по линии укреплений казачество несло в них пограничную службу, выполняя эту миссию вплоть до упразднения у городов и селений статуса крепостей и редутов. В 1741 г. в посёлках Московской дороги проживало более 6 тыс. чел.
И.И. Неплюев, ознакомившись с положением в крае, пришёл к заключению о необходимости в короткие сроки обустроить край. Именно И.И. Неплюеву удалось заселить необъятную территорию [9, c. 91]. Данные ревизий позволяют представить картину демографических преобразований в крае: по II ревизии (1744 г.) проживало 282 тыс. чел.; по III (1763 г.) - 427 тыс. чел.; по IV (1782 г.) - 600 чел.; по V (1795 г.) - 760 тыс. чел. Население губернии с момента образования увеличилось в 3 раза.

Освоение края, получившего позднее наименование - Оренбургский, сразу же после основания первых посёлков вызвало недовольство казахов и сопровождалось их постоянными набегами. Предки современных казахов в документальных источниках XVIII - начала XX вв. именовались «киргизами» или «киргиз-кайсаками». В период возведения крепостей и редутов кочевья казахов приближались к Яику периодически, поскольку трассы их передвижений носили сезонный характер и пролегали с юга на север и наоборот [10].

Набеги степняков ставили под угрозу планы построения Оренбурга [11, л. 55-70]. Казахи атаковали «редут Честного Креста» между Сорочинской и Новосергиевской крепостями имеющийся, однако никакой удачи не получили от показанного редута с немалом уроном отбиты...». Провалился и ночной набег на Сорочинскую крепость, где находился сын хана Малого жуза. На границу вынуждены были дополнительно направить воинские соединения. В связи с этими событиями в документе сказано: «по собрании коих пакости и наглости киргиз-кайсацкие удержаны».

Для решения вопроса «о прекращении оных злодейств» в Оренбурге состоялся совет командиров, на котором обсуждалась тактика дальнейших действий. И.И. Неплюев, руководитель Оренбургской комиссии, и генерал фон Штокман в начале 1744 г. составили «генеральный план», предусматривавший все необходимые меры «к конечному и совершенному таких киргиз-кайсацких наглых и злодейственных поступок пресечению..., чтоб во время потребностей всегда по тому поступать и действовать». 14 января 1744 г. план отправили в Сенат.

Наиболее дерзкий набег казахи под предводительством султана Дербешалея осуществили на Рассыпную летом 1743 г. (Н. Фирсов Чернореченскую и Татищевскую называет крепостями, говоря же о Рассыпной, пишет: «в урочище Рассыпном») [6, с. 387]. В работе П.И. Рычкова «Топография Оренбургской, то есть: обстоятельное описание Оренбургской губернии» рассказывается о трагедии, произошедшей в ней: 
«Рассыпная (обратим внимание на тот факт, что П.И. Рычков не называет Рассыпную крепостью), при реке Яике, от Илецкого казачьего городка вверх 25, а от Оренбурга вниз 101 верста. Сначала поселено было там по самопроизвольному желанию малороссиян до ста дворов, но по причине той, что в 1743 году киргиз-кайсаки из бывших на жнитве хлеба безоружейно захватили их в плен мужеска и женска полу восемьдесят двух человек и что они в таком месте, от которого киргизцы кочуют в близости и где прежде бывали частые воровские перелазы, по их неосторожности к пребыванию усмотрены оплошными и неспособными, некоторые уволены в Украйну на прежние их жительства, а другие самоохотно перешли на житье на реку Кинель. По сведении ж их, оттоль определен и ныне находится тут гарнизон, рота драгунская да полторы пехотной» $[12$, c. 307].

После дерзких вылазок казахов в 1743 г. большая часть малороссов решилась оставить Оренбургский край. И.И. Неплюев охотно согласился на это, донося в Сенат: «От жительства их при самой границе никакой пользы не предвидится, но паче и опасно, чтобы их, неосторожных и слабых людей, киргизкайсаки внезапными набегами не растаскали».

Несмотря на то, что казахи «вступили во Всероссийское подданство» в 1731 г., в 1732 и 1738 гг. они разграбили торговые караваны, отправленные в Хиву. Кочевники в 1743 г. напали на редуты оренбургского ведомства, и «между строящихся крепостей многое число российских людей побили и в плен позабрали» $[13$, с. 27]. Кроме того, казахи ежегодно «многолюдным собранием» ходили на Волгу, «разоряли и захватывали в плен» российских подданных калмыков. В ходе внезапных набегов они воровали скот, грабили жителей и «разделяясь на разные партии, выжигали степь», но, встретив сопротивление, «ретировались с великой поспешностью» [14, л. 4].

Поэтому в Коллегии иностранных дел считали, что никакой пользы и интереса для государства «от их подданства не было» $[13$, л. 27]. Чтобы они (казахи) были «от российских границ вдаль отбиты» без применения регулярных войск, Коллегия иностранных дел предлагала дать разрешение калмыкам, яицким казакам, башкирам и другим иноземцам Сибирской губернии и русским подданным самостоятельно наказывать лиц, вторгшихся на российскую территорию. Однако данное предложение отклонили.

Непрекращающиеся нападения кочевников на российских подданных стали основанием для ответных действий. 13 августа 1743 г. вышел именной указ о задержании в Москве «Абулхаировых посланцев». Оренбургскому губернатору И.И. Неплюеву поручалось задержать сына Абулхаира (Ходжа Ахмет Салтана - Кожахмета), находившегося в Оренбургской губернии, до освобождения всех российских пленных [11, л. 107-108].

В результате к концу 1743 г. Абулхаир возвратил на родину 48 российских подданных, находившихся в плену казахов, однако Кожахмета не отпустили.

29 мая 1744 г. от оренбургского губернатора И.И. Неплюева потребовали усилить надзор за находящимся в Сорочинской крепости сыном хана Абулхаира, который «изыскивает меры... освободить его или выкрасть» $[14$, л. 156]. Истинной причиной для задержания Кожахмета являлись «недружественные» поступки хана Абулхаира. Арест сына должен был стать залогом его дружеского расположения.

Абулхаир в ноябре 1747 г. обратился к императрице Елизавете Петровне с жалобой на действия И.И. Неплюева, отказавшегося принять от него три просьбы:

1. Дозволить задерживать «глупых людей, от которых противные поступки и неповиновения», в том числе жителей Среднего или Младшего жуза, «которыми противность показана была»;

2. Отправить Абулхаиру «для походов на дальних неприятелей» пушек и людей, «дабы отворить дороги» торговым караванам в Бухару;

3. Освободить Ходжа Ахмет Салтана.

В ответ на обвинения в нежелании прекратить нападения на российских подданных, Абулхаир заявил: «Я за киргиз-кайсак не стою и их не жалею» $[15$, л. 23 об.]. Коллегия иностранных дел удовлетворила только одну просьбу. Абулхаиру дозволили «подлых киргиз-кайсак от непристойных и всему вашему народу вредных поступков унимать» $[15$, л. 27 об.].

После гибели Абулхаира следующий правитель Младшего жуза - его сын Нурали-хан - был приведен к присяге на верность Всероссийской императрице 8 июля 1749 г. Перед началом торжественной церемонии казахи по обычаю пили за ее здравие кумыс, а также молились за здравие Оренбургского губернатора [16, л. 121].

Нурали-хан вместе со свитой расположился лагерем в пяти верстах от Оренбурга. Ему публично был дарован патент, чин и присланные в подарок от императрицы шуба, шапка и сабля. Нурали-хан поклялся, что будет обстоятельно доносить Государственной Военной коллегии обо всём, что происходит в его землях [17, л. 82].

Самовольный переход казахами границы кочевий и перегон ими табунов лошадей на пастбища, принадлежавшие казакам, «за неимением корма» в степи являлся значительной проблемой, требовавшей вмешательства Оренбургского губернатора. Например, в 1754 г. казахи Среднего жуза, подчинявшиеся Аблай Солтану, вторглись для кочевья на территорию Оренбургской губернии после угроз со стороны его брата хана Мамета - поджечь сено и задержать людей.

Отряд драгун, высланный навстречу к откочевавшим на российскую территорию казахам, чтобы вынудить их возвратиться в Степь, жестоко избили и ограбили. Для наказания кочевников организовали вооружённый отряд, включавший пехоту, который задержал 23 человека вместе с украденными у драгун лошадьми. Однако Оренбургский губернатор И.И. Неплюев получил приказ отпустить задержанных в их улусы «без всякого озлобления» [18, л. 29].

Причиной большинства споров, возникавших между казахами и яицкими казаками, являлись взаимные обвинения в воровстве скота. Так, в 1755 г. у Нурали-хана изъяли сотню лошадей, похищенных у яицких казаков. В ответ на обвинения в поддержке воровства скота Нурали сообщил, что его люди «взяли их вместо баранов, угнанных казаками». По итогам расследования, проведенного Оренбургским губернатором И.И. Неплюевым, украденных казаками баранов возвратили хозяевам. 
XIX век не принёс облегчения в жизни казаков. Кочевники продолжали нападать на казаков и их домочадцев [19]. Летом 1841 г. в Уральскую войсковую канцелярию поступил приказ: «По случаю наступления летнего времени, в которое чаще обыкновенного обнаруживаются со стороны хищных киргизов неблагонамерные покушения, считаю нелишним строжайше предупредить о неупустительном исполнении правил и точном соблюдении мер осторожности».

Для того чтобы передать колорит прошлого, приводим архивные материалы, касающиеся лишь одной крепости. Из Рассыпной попали в плен следующие оренбуржцы:

«1. Казак Пётр Недопёкин был взят в начале столетия, приблизительно в 1802-1805 гг., у самой крепости Рассыпной, на пристани через реку Урал, куда он на утренней заре гонял поить лошадей. Киргизы его избили, связали руки назад и увезли в аулы за Илек. Год держали в железах, а потом пас баранов. В плену он пробыл 12 лет и вышел благодаря киргизке, которая дала ему коня отличного. Выбежал он на Каспийском море зимой под Гурьев, шёл по льду и наткнулся на уральских казаков, бывших на ... рыболовстве. Уральцы подъехали на его голос, взяли его и трое суток давали ему только по рюмочке и сухарику, а потом стали прибавлять пищи и кормить варевом. Когда он уже достаточно поправился, его представили в Гурьев, а оттуда в Оренбург и Рассыпную, куда он и прибыл к Христовой заутренне. Лишь только помолившись и поздоровавшись с матерью дома, он тотчас отправился в церковь. Народ его узнал и заговорил в церкви: «Пётр Недопёкин пришёл! Недопёкин пришёл!», а голова у него была бритая, он повязал её платочком. От правительства никаких наград не получил, а потом на Афонскую гору, где поступил в монахи и умер. В Рассыпной он оставил мать и жену; детей у него не было».

Это рассказал Дмитрий Терентьевич Мясников, 92-х лет.

2. Степанида Боборыкина была взята в плен на пристани у самой Рассыпной, когда ходила вечером с вёдрами за водой; умерла в плену, и об её участи ничего не известно.

3-6. Малолетние Пётр, Иван, Яков и Пелагея Смутинины были взяты с жнитва, но с Филипповского пикета бросились казаки и преследовали киргизов по р. Песчанке, впадающей в Илек, а через Урал киргизы переправились в брод. Взятые в плен были отбиты на другой день, причём один киргиз был убит, а двое скрылись.

7. Филат Тулаев был схвачен на дороге из Рассыпной в Буранную и пробыл в плену три года. Каждую ночь его привязывали к кибитке закованного, но особым истязаниям не подвергали. Ушёл он из плена благодаря тому, что киргизка дала ему лошадь. Он выбежал на Илецкую Защиту, а потом пришёл в Буранную; по-киргизски он говорил очень хорошо.

8. Василий Ленивов был взят вместе с Тулаевым и был продан в Хиву, где умер, живя работником.

9 и 10. Иван и Фёдор Хохулины и старуха Любовь Смирнова ехали из Рассыпной в Буранную; оружия с ними не было. Не доезжая Филипповского пикета, на них напали пятеро киргизов, мужчин пленили, а старуху убили. Хохулиных отбили с Филипповского пикета: киргизы, увидя погоню, бросили их.
11. Василий Новиков приблизительно в 18101820 гг. был взят тоже на пути в Буранную и не возвращался.

12. Есаульский сын Максим Трофимович Попов попал в плен ночью в 1823 г., будучи в разъезде с двумя башкирами, которых киргизы не взяли. Пробыл в плену три года. На ночь ему связывали руки, ноги заковывали в железа и привязывали к кибитке, а днём пас баранов и в это время с ним в вид караульщика посылался киргиз. Около полугода он голодал, а потом ел маханину. Попов решился бежать на лошади, руководствуясь звёздами, но его поймали вскоре и после этого подрезали пятки и набили рубленным волосом. Так пробыл два года, из которых один каждые сутки был закован и днём и ночью.

Один богатый киргиз выкупил его за 100 баранов и доставил в Рассыпную. Комендант Рассыпной, майор Илларион Петрович Подгорный, отправил киргиза в Оренбург, где того обласкали и дали кафтан с галунами. На возвратном пути из Оренбурга киргиз заехал в Рассыпную, остановился у Максима Трофимовича и показывал подаренный ему зипун. Попов получил урядника; при возвращении он был одет в киргизский зипунишко и длинную, ниже колен, рубаху».

Пётр Фёдорович Смутинин, 75 лет:

«Я с братьями и сестрою был взят в плен при таких обстоятельствах: приблизительно в 1823 году старший брат Иван, сестра Пелагея, 13 лет, я, 19 лет, и грудной Яков были на молотьбе на урочище Соколовом в пяти верстах от Рассыпной на правой стороне Урала. К нам подъехало двое киргиз с шестью лошадьми и взяли. Иван пробовал защищаться и обрубил одну пику топором, но получил удар чеканом между крылец и был взят. Привязавши нас к торокам и связавши ноги под брюхом лошади, а Якова - к туловищу полотенцем, киргизы переехали Урал и долго плутали, а мы кидали по дороге знаки: где коть (ботинок), где чулок, где на переправе повесим крестик с шеи, чтобы обозначить путь. Так возили нас киргизы два дня, давали дорогою немного кумы, да было с нами по кусочку хлеба, чего, разумеется, было недостаточно. На речке Песчанке киргизы остановились отдыхать, и тут подъехал человек, который стал креститься. Увидав это и поняв, что перед нами русский, мы тоже стали креститься и вскоре подъехал ещё конный, тоже казак-башкирец. Спросивши, сколько киргиз и узнавши, их двое, первый приехавший, казак Пётр Фокин, сказал башкиру, что он должен прикончить одного киргиза, а другого башкирин должен гнать на пикет. На пикете нас и киргиза одного приняли и потом последнего со мной и Иваном отправили в Оренбург, где губернатором в то время был Фаленгарть (Эленгардт). С тех пор, от муки встряски, я, Пётр Смутинин, страдаю, совершенно разбитый» [20, с. 154-158]».

Мы привели некоторые сведения только по одной крепости. Не лучше выглядела ситуация в других населённых пунктах.

В течение длительного времени отношения с казахами не улучшались. «В глазах казаков зауральские киргизы были не что иное, как враги, - писал И.И. Железнов. Процесс присоединения Казахстана к России затянулся более чем на целое столетие.

Ввиду постоянной опасности набегов издавалось множество инструкций и наставлений, которые часто 
менялись. Главным в них оставалось указание: во время рыбной ловли, сенокосов и других массовых мероприятий следует рядом держать вооружённую команду.

Несмотря на множество конфликтных ситуаций, часть казахской знати принимала участие в наведении порядка в степи. Дальновидные правители казахских жузов и России нашли в XVIII в. единственно верное и разумное решение, договорившись о сближении своих народов, встав на путь взаимовыгодного экономического и политического сотрудничества вплоть до слияния в единое государство, несмотря на трудности, возникшие на этом пути [21-23].

Сегодня Казахстан совсем другая страна, быстро развивающаяся. Государство-миротворец, где проходят переговоры по урегулированию сирийского конфликта, формируются финансовые институты Евразийского экономического союза. «Мы - Оренбургская область - с Казахстаном не просто дружим и торгуем. Наше общение почти семейное». Дни Оренбургской области в Актобе 18-19 мая 2018 г. тому доказательство. В приветственном слове Акима Актюбинской области Бердыбека Сапарбаева прозвучало главное: «Мы должны вместе жить и работать согласно завету наших дедов и прадедов и согласно поручению наших президентов» $[24$, с. 8$]$.

\section{Список литературы:}

1. Мансуров Т.А. Казахстан и Россия: суверенизация, интеграция, опыт стратегического партнёрства. М.: Русский Раритет, 1997. 368 с.

2. История Казахстана с древнейших времён до наших дней. Алматы: Изд-во «Даур», 1993. 456 с.

3. Ирмуханов Б.Б. Казахстан: историко-публицистический взгляд. Алматы: Олке, 1996. 79 с.

4. Страна в сердце Евразии (сюжеты по истории Казахстана) / под ред. К.Н. Бурханова и др. Алматы: Казах. ун-т, 1998. 280 с.

5. Государственный архив Оренбургской области (ГАОО). Ф. 2. Оп. 1. Д. 13.

6. Фирсов Н.А. Инородческое население прежнего Казанского царства в новой России до 1762 года. Казань: Унив. тип., 1869. 445 с.
7. Смирнов Ю.Н. Оренбургская экспедиция (комиссия) и присоединение Заволжья к России в 3040-е гг. XVIII века. Самара: Изд-во «Самарский университет», 1997. 190 с.

8. Поляков А.Н. Илецкие казаки в XVIII в. // История Оренбургская: наследие и современность: сб. ст. в 2 т. Т. 1. Оренбург: Изд-во Оренб. гос. пед. унта, 2006. С. 89-91.

9. Оренбургская губерния 1744-1750 // Материалы по историко-статистическому описанию Оренбургского казачьего войска. Оренбург: Тип. О. Яковлева, 1912. Вып. 7. С. 47-50.

10. Вельяминов-Зернов В.В. Исторические известия о киргиз-кайсаках и сношениях России со времени кончины Абул-Хайр Хана (1748-1765). Уфа, $1855.64 \mathrm{c}$.

11. ГАОО. Ф. 1. Оп. 1. Д. 1.

12. Рычков П.И. Топография Оренбургской губернии. Оренбург: Оренбург. отд. Император Рус. геогр. об-ва, 1887. 405 с.

13. ГАОО. Ф. 3. Оп. 1. Д. 13.

14. ГАОО. Ф. 3. Оп. 1. Д. 2.

15. ГАОО. Ф. 3. ОП. 1. Д. 14.

16. ГАОО. Ф. 3. Оп. 1. Д. 18.

17. ГАОО. Ф. 3. Оп. 1. Д. 21.

18. ГАОО. Ф. 3. Оп. 1. Д. 37.

19. Киргизская степь Оренбургского ведомства // Записки Оренбургского отделения Русского географического общества. Оренбург: Тип. Б.А. Бреслина, 1881. Вып. IV. С. 98-118.

20. Столпянский П.М. Материалы по историкостатистическому описанию Оренбургского казачьего войска. Вып. І. Оренбург: Тип. Н.Г. Волкова, 1903. 63 с.

21. Бекмаханов Е.В. Присоединение Казахстана к России. Алма-Ата: Изд-во АН СССР, 1957. 337 с.

22. Апполова Н.Г. Экономические и политические связи Казахстана с Россией в XVIII - начале ХІХ вв. М.: Изд-во АН СССР, 1960. 456 с.

23. Касымбаев Ж.К. Под надёжную защиту России. Алма-Ата: Казахстан, 1986. 184 с.

24. Оренбург - Актобе: в одной степи через границу // Оренбуржье. 2018. 23 мая. С. 8-9.

\section{ETHNIC AND ADMINISTRATIVE BORDERS: FROM CONFLICT TO STABILITY (ON THE EXAMPLE OF ORENBURG REGION IN XVIII-XIX CENTURIES)}

(C) 2018

Fedorova Alla Vladimirovna, doctor of historical sciences, professor of History and Philosophy Department Orenburg State Agrarian University (Orenburg, Russian Federation)

Abstract. Understanding the historical experience of relations between peoples affects the political, economic and cultural sphere of people's lives. Ethno-cultural and inter-confessional dialogue in the multi-ethnic space is always in the spotlight of researchers. Over the past two and a half centuries more than 50 thousand scientific works devoted to the history of Kazakhstan of the pre-revolutionary period were published in different regions of the former USSR and abroad. Historians of Russia and Kazakhstan, using an extensive documentary base, study all aspects of the interaction of their peoples. As before, the subject of discussion is a multifaceted problem of Russian-Kazakh relations, in particular, the entry of Kazakhstan into the Russian Empire in the early XVIII century. The paper deals with the nature of this connection in the context of cross-border region relations. The author relies on an approach that is free from emotional influence and reflects both negative and positive consequences of the Empire's national policy. Colonization of the Kazakh steppe began with the territory of the southern Urals; the paper demonstrates the conflict potential, the confrontation of tsarism and Kazakh society. The author shows on the materials of Orenburg Region that despite all the vicissitudes of history the Kazakhs and the Russian people have developed sincere relations of good neighborliness and cooperation.

Keywords: Russia; Kazakhstan; Orenburg province; Ilek fortress; Ilets fortress; Sorochinskaya fortress; Rassipnaya fortress; Orenburg Commission; border line; Yaitsky Cossacks; audit; little Russians; Board of foreign Affairs; I.I. Neplyuev; demography; Kirghiz-kaysaki; Middle Zhuz; Junior Zhuz; nomads; captivity; Abulkhair; Nurali Khan; raids. 